\title{
Kajian Profil Kearifan Lokal Lilifuk : Traditional Ecological Knowledge (TEK) di Desa Kuanheum
}

\author{
Study of Local Wisdom Profile of Lilifuk: Traditional Ecological Knowledge \\ (TEK) in Kuanheum Village \\ Joi Alfreddi Surbakti ${ }^{1 *}$,Sondang P.P Leonak ${ }^{1}$ \\ ${ }^{1}$ Program Studi Agribisnis Perikanan, Politeknik Pertanian Negeri Kupang \\ Jl. Prof. Herman Yohanes Kelurahan Lasiana Kota Kupang \\ *Korespondensi: surbaktijoy@gmail.com
}

\begin{abstract}
ABSTRAK
Penelitian ini dilaksanakan di Desa Kuanheum Kecamatan Kupang Barat, Kabupaten Kupang, Nusa Tenggara Timur pada bulan Mei hingga Juni 2020. Tujuan dari penelitian ini adalah mendeskripsikan nilai-nilai kearifan lokal apa saja yang terdapat pada masyarakat pesisir Desa Kuanheum Kabupaten Kupang. Metode penelitian yang digunakan dalam penelitian ini adalah metode deskriptif kualitatif dan studi kasus dengan pendekatan studi etnographic. Jumlah responden yang diambil sebanyak 30 orang. Responden terdiri dari tetua adat, kepala desa, dan perwakilan lembaga swadaya masyarakat. Konsep pengelolaannya Lilifuk bersifat community based management Model membangun pengelolaan berbasis pada pendekatan subyektif dan pendekatan struktural.
\end{abstract}

Kata kunci: Kearifan lokal; Desa Kuaheum; Kawasan Teluk Kupang

\begin{abstract}
This research was conducted in Kuanheum Village, West Kupang District, Kupang Regency, East Nusa Tenggara from May to June 2020. The purpose of this study is to describe the values of local wisdom found in the coastal communities of Kuanheum Village, Kupang Regency. The research method used in this research is descriptive qualitative method and case studies with an ethnographic study approach. The number of respondents taken was 30 people. Respondents consist of traditional elders, village heads, and representatives of non-governmental organizations. The management concept of Lilifuk is a community based management model to build management based on a subjective approach and a structural approach.
\end{abstract}

Keywords:Local Wisdom; Kuanheum Village; Kupang Bay Area

\section{PENDAHULUAN}

Sumberdaya alam yang baik akan meningkatkan kesejahteraan umat manusia, dan juga sebaliknya yaitu jika pengelolaan sumber daya alamnya tidak baik, maka akan berdampak buruk bagi umat manusia. Pengelolaan sumber daya alam yang arif dan berkelanjutan diperlukan untuk mengantisipasi peningkatan degradasi lingkungan. Menjaga kelestarian sumberdaya dan meningkatkan kesejahteraan seluruh masyarakat di wilayah pesisir dan pulaupulau kecil menjadi tujuan utama dan pengelolaan sumberdaya wilayah pesisir dan laut. Berbagai aspek seperti aspek ekologi, sosial dan budaya masyarakat lokal harus diperhatikan dan dipertahankan sebagai landasan pengelolaan sumberdaya yang berkelanjutan. Aspek ekologi dapat diwujudkan dalam fungsi-fungsi ekosistem, sedangkan aspek sosial budaya 
dapat dilihat dari kearifan lokal dalam suatu daerah. Aspek-aspek tersebut merupakan modal utama untuk mencapai kelestarian sumberdaya dan kesejahteraan masyarakat pesisir (Fauzi, 2004).

Masyarakat adat merupakan sekumpulan orang yang hidup bersama dalam satu wilayah serta memiliki hubungan keterikatan sebagai satu kerukunan. Hutan, tanah, sungai, pesisirserta gunung memiliki keterikatan tersendiri dengan mereka. Kawasan pesisir bukan hanya sebagai suatu ekosistem tempat adanya ikan yang bisa digunakan dan dimanfaatkan untuk kepentingan manusia. Bagi masyarakat adat, lingkungan tempat tinggal mereka merupakan simbol dari sebuah harga diri (Berkes, 1995)dalam Sulaiman (2010).

Wilayah pesisir yang panjang disertai keaneka ragaman suku menyebabkan hampir disetiap pesisir Indonesia memiliki adat istiadat yang variatif. Adat istiadat masyarakat pesisir yang di dominasi oleh nelayan ini salah satunya adalah kearifan lokal atau lokal wisdom. Peran dan status kearifan lokal sebagai hukum atau aturan yang dilaksanakan di wilayah-wilayah pesisir ini sangat penting mengingat dari sisi historinya yang didapatkan dalam proses yang sangat panjang dan diturunkan secara lisan oleh masyarakat secara turun menurun. Apalagi dari segi tujuan diterapkannya yaitu sebagai kontrol terhadap sifat manusia yang kebutuhan dan keinginannya tidak terbatas memungkinkan keberadaan kearifan lokal sangat mempengaruhi kelestarian lingkungan manusia sebagai tempat tinggal khususnya wilayah pesisir.

Kearifan lokal merupakan tata nilai kehidupan yang terwarisi dari satu generasi ke generasi berikutnya yang berbentuk religi, budaya ataupun adat istiadat yang umumnya dalam bentuk lisan dalam suatu bentuk sistem sosial suatu masyarakat. Keberadaan kearifan lokal dalam masyarakat merupakan hasil dari proses adaptasi turun menurun dalam periode waktu yang sangat lama terhadap suatu lingkungan yang biasanya didiami ataupun lingkungan dimana sering terjadi interaksi didalamnya(Juniarta, 2013).

Sedangkan menurut Ridwan (2007) Kearifan lokal atau sering disebut local wisdom dapat dipahami sebagai usaha manusia dengan menggunakan akal budinya (kognisi) untuk bertindak dan bersikap terhadap sesuatu, objek, atau peristiwa yang terjadi dalam ruang tertentu. Pengertian di atas, disusun secara etimologi, di mana wisdom dipahami sebagai kemampuan seseorang dalam menggunakan akal pikirannya dalam bertindak atau bersikap sebagai hasil penilaian terhadap sesuatu, objek, atau peristiwa yang terjadi. Sebagai sebuah istilah, wisdom sering diartikan sebagai kearifan/kebijaksanaan. Lokal secara spesifik menunjuk pada ruang interaksi terbatas dengan sistem nilai yang terbatas pula. Sebagai ruang interaksi yang sudah didesain sedemikian rupa yang di dalamnya melibatkan suatu pola-pola hubungan antara manusia dengan manusia atau manusia dengan lingkungan fisiknya.

Indonesia banyak memiliki kearifan lokal yang menjadi contoh dalam pengelolaan lingkungan yaitu salah satunya Panglima Laot, Awig-awig dan Mane'e. Seluruh kearifan lokal tersebut diterapkan turun menurun oleh masyarakat setempat misalnya untuk panglima laot di Aceh dan awig-awig di Buleleng Bali dan keberadaannya sangat mempengaruhi kelestariaan lingkungan setempat.

Keikutsertaan masyarakat lokal dan kearifan lokal diakui secara hukum dalam peraturan perundang-undangan Indonesia. Hal ini seiring dengan adanya perubahan rezim pemerintahan dari sentralisasi ke desentralisasi mengubah sistem hukum Indonesia, termasuk di bidang kelautan dan perikanan dimana kewenangan pengelolaan wilayah pesisir dan laut dapat melibatkan masyarakat lokal melalui kemitraan dan mendorong masyarakat untuk berpartisipasi dalam pengelolaan wilayah pesisir dan laut.

Mengacu pada latar belakang penelitian maka dirumuskan permasalahan 
penelitian sebagai Bagaimana cara mengindentifikasi kearifan lokal yang ada di Kawasan Teluk Kupang yang mendukung pengembangan perikanan berkelanjutan

\section{METODE PENELITIAN}

Tempat penelitian ini dilaksanakan di Desa Kuanheum, Kecamatan Kupang Barat, Kabupaten Kupang yang berada dalam wilayah Provinsi Nusa Tenggara Timur. Penentuan lokasi ini karena Desa Kuanheum memiliki kearifan lokal dan perikanan yang mendukung perekonomian masyarakat. Waktu penelitian dilaksanakan di Bulan Mei 2020 sampai dengan Juni 2020. Data yang dikumpulkan dalam penelitian ini terdiri dari data primer dan data sekunder. Data sekunder diperoleh dari analisis dokumen yang bersifat hasil penelitian seperti buku, makalah dan skripsi. Untuk pengumpulan data primer, dilakukan dengan pengamatan dan wawancara mendalam (indepth interview) serta wawancara yang dipandu dengan instrumen penelitian berupa kuesioner.

Informasi mengenai pengelolaan sumber daya Lilifuk dikumpulkan melalui wawancara mendalam dengan tokoh masyarakat seperti tetua adat, kepala desa, dan perwakilan lembaga swadaya masyarakat dengan menggunakan pedoman wawancara/ topik data dan menggunakan alat bantu rekam. Jumlah responden pada penelitian ini adalah 30 responden dan diambil secara acak menurut peranan mereka dalam pemanfaatan dan pendayagunaan lilifuk di Desa Kuanheum

Penelitian ini, teknik penentuan sample dilakukan dengan purposive sample yaitu dengan menentukan secara acak atau random. Prosedur pemilihan berdasarkan pada peranan mereka dalam pemanfaatan dan pendayagunaan lilifuk. Karena penelitian ini merupakan penelitian dengan metode deskriptif kualitatif, ketika data atau informasi yang didapat sudah mewakili dan dianggap valid dari seorang informan maka data sudah mewakili dari semua sampel yang akan diteliti. Jumlah responden untuk penelitian ini adalah 30 responden

\section{Metode Analisis Data}

Metode penelitian yang digunakan dalam penelitian ini adalah metode deskriptif kualitatif dan studi kasus dengan pendekatan studi etnographic. Metode ini digunakan karena berkaitan dengan kajian kearifan lokal yang menggunakan data-data dari informan. Menurut Idrus (2009), studi kasus merupakan desain penelitian pada pendekatan kualitatif maupun kuantitatif yang mempelajari suatu individu maupun unit sosial tertentu secara mendalam yang bersifat alami, holistik, mengandung unsur budaya, serta memiliki pendekatan fenomologi.

Dalam penelitian ini, peneliti menggunakan pendekatan etnografi. Menurut Sukmadinata (2006) dalam Mardoyo (2008) Studi etnografi (ethnographic studies) mendeskripsikan dan menginterpretasikan budaya, kelompok sosial atau sistem. Meskipun makna budaya itu sangat luas, tetapi studi etnografi biasanya dipusatkan pada polapola kegiatan, bahasa, kepercayaan, ritual dan cara-cara hidup. Seorang etnografer memfokuskan perhatiannya pada detildetil kehidupan lokal dan menghubungkannya dengan prosesproses sosial yang lebih luas.

Pengamatan yang dilakukan dalam penelitian ini adalah kondisi sosial kultural kemasyarakatan dan kondisi sumber daya perikanan. Wawancara dilakukan untuk mendapatkan informasi mengenai pengelolaan sumber daya, kearifan lokal.

\section{HASIL DAN PEMBAHASAN}

\section{Gambaran Umum Lokasi Penelitian}

Secara geografis Kabupaten Kupang terletak pada $121^{\circ} .30^{\prime}$ BT $124^{\circ} .11^{\prime}$ BT dan $9^{\circ} .19^{\prime} \mathrm{LS}-10^{\circ} .57^{\prime} \mathrm{LS}$. Luas wilayah Kabupaten Kupang seluas $53.958,28 \mathrm{Km}^{2}$ yang terdiri dari wilayah daratan seluas $7.178,28 \mathrm{Km}^{2}$ dan wilayah laut seluas $46780 \mathrm{Km}^{2}$ dengan garis pantai $\pm 492,4 \mathrm{Km}$.

Lokasi penelitian ini terletak di Kecamatan Kupang barat. Kecamatan 
Kupang Barat terdiri dari 10 desa dan 2 kelurahan dan memiliki luas $149,72 \mathrm{~km}^{2}$. Penelitian ini dilakukan di Desa Kuanheum.

Desa Kuanheum memiliki jumlah penduduk sebanyak 1.482 jiwa yang terdiri dari 359 Kepala Keluarga dan jumlah yang berjenis kelamin laki-laki sebanyak 736 jiwa dan yang berjenis kelamin perempuan sebanyak 746 jiwa.

Wilayah Desa Kuanheum terletak di daerah pesisir. Sehingga sebagian besar penduduk desa bermata-pencaharian sebagai nelayan. Berdasarkan hasil pengamatan, masyarakatmemanfaatkan sumber daya tersebut sebagai bahan makanan dan sumber mata pencahariannya. Hasil tangkapan masyarakat nelayan umumnya digunakan sebagai bahan makanan keluarga dan sisanya dijual untuk mendapatkan uang.

Potensi ikan karang yang masih banyak hal ini dikarenakan terdapat banyak padang lamun diantaranya jenis Thalassia hempricii dan Enhalus acaroides. Tutupan lamun yang sangat tinggi juga menjadikan potensi ikan karang yang cukup besar.

Beberapa jenis ikan yang dapat ditemukan di pesisir Desa Kuanheum yang merupakan daerah pasang surut tersebut diantaranya ikan Beronang (Siganus spp.), Alu-alu (Sphyranidae), Kerapu (Ephinephelus spp.), dan Peperek (Leigonathidae).

Kerusakan terumbu karang yang terjadi di Desa Kuanheum dikarenakan oleh aktivitas manusia seperti penangkapan ikan terutama penangkapan pada saat surut dengan mengambil semua jenis ikan baik yang besar maupun yang masih kecil. Selain itu juga kerap dilakukan pengeboman oleh nelayan yang dianggap mudah karena tidak memakan biaya yang banyak serta menghasilkan banyak tangkapan dalam waktu singkat. Penambangan karang juga sering dilakukan masyarakat untuk dijadikan sebagai bahan bangunan seperti dermaga, rumah dan pagar, pembuatan kapur serta pembuatan jalan.

Penduduk Desa Kuanheum merupakan masyarakat yang heterogen yang teridir atas beberapa suku besar antara lain: Suku Timor Helong, Rote, Sabu, Timor Dawan, Flores dan sukusuku lainnya. Pada umumnya agama yang dianut oleh masyarakat Desa Kuanheum adalah Kristen Protestan disamping agama Katholik dan Islam. Walaupun demikian dalam kehidupan di antara sesama umat beragama senantiasa penuh dengan keharmonisan.

\section{Potensi Sumber Daya Perikanan}

Berdasarkan hasil pengamatan pada saat penelitian masyarakat memanfaatkan sumber daya tersebut sebagai bahan makanan dan sumber mata pencahariannya. Hasil tangkapan masyarakat nelayan umumnya digunakan sebagai bahan makanan keluarga dan sisanya dijual untuk mendapatkan uang.

Dari data dan informasi yang diperoleh selama penelitian sebaran potensi sumberdaya ikan dan non ikan untuk beberapa jenis ikan baik pelagis besar dan ikan demersal ya ng dominan tertangkap oleh nelayan, cenderung menyebar pada perairan laut Kabupaten Kupang. Namun demikian jenis -jenis ikan tertentu seperti kakap dan kerapu biasanya tertangkap di sekitar perairan lo kasi penelitian. Beberapa jenis ikan yang tertangkap seperti ikan kembung, ikan tembang, ikan terbang, julung-julung dan ikan selar.

Jenis-jenis ikan yang ditangkap dan alat tangkap dengan menggunakan adalah ramah lingkungan (Surbakti, 2019). Hal ini untuk menjaga lestarian jenis ikan yang ada di perairan tersebut.

\section{Kondisi Sosial Ekonomi Masyarakat}

Masyarakat Kupang terdiri dari beberapa suku diantaranya suku Tetun, Helong, Flores, dan Rote. Penduduk desa Bolok terdiri dari berbagai suku asli Nusa Tenggara Timur (NTT) dan berbagai suku dari luar NTT. Dominasi suku yang ada di Desa Kuanheum berasal dari suku Helong. Sekarang, dari suku-suku tersebut terdapat 13 marga yang mendiami desa tersebut yang awalnya hanya 7 marga asli. Meskipun terdapat berbagai etnis dengan berbagai budaya yang berbeda, namun 
masyarakat desa ini tinggal secara akur dan damai hidup berdampingan dalam kehidupan sehari-hari (Boikh, 2010).

Jumlah penduduk yang bermatapencaharian sebagai petani lebih banyak daripada nelayan. namun mereka lebih menggantungkan hidupnya sebagai nelayan dalam pemenuhan proteinnya. Mereka menangkap ikan setiap hari untuk memenuhi kebutuhan protein keluarga, tidak untuk dijual. Data penduduk berdasarkan matapencaharian dapat dilihat pada Tabel 1.

Tabel 1. Jumlah Penduduk Desa Kuanheum Berdasarkan Pekerjaan

\begin{tabular}{llc}
\hline No & $\begin{array}{c}\text { Mata } \\
\text { Pencaharian }\end{array}$ & $\begin{array}{c}\text { Jumlah } \\
\text { (orang) }\end{array}$ \\
\hline 1. & PNS & 14 \\
\hline 2. & Nelayan & 150 \\
\hline 3. & Petani & 489 \\
\hline 4. & Wiraswasta & 88 \\
\hline 5. & Lainnya & 29 \\
\hline Data: & BPS Kabupaten Kupang (2019)
\end{tabular}

\section{Potensi Kearifan Lokal Lilifuk}

Lilifuk adalah cara mengelola sumberdaya laut yang dikenal di Kecamatan Kupang Barat. Lilifuk merupakan suatu kawasan di perairan laut yang berbentuk kolam yang tergenang pada saat air laut surut. Pada saat surut ini ikan banyak yang terperangkap di dalamnya. Karena itu, masyarakat kemudian mengelola sumber daya ini untuk ditutup dari aktivitas penangkapan ikan sehari-hari dan dibuka untuk sekali atau dua kali dalam setahun sesuai dengan kesepakatan untuk dapat dimanfaatkan. Lilifuk tersebut merupakan hak milik dari suatu suku tertentu dengan pengelolaannya dilindungi oleh hukum adat.

Lilifuk yang ada di Kabupaten Kupang terdapat 3 buah yaitu Lilifuk Baimusu dan Lilifuk Gatal di Desa Bolok, serta Lilifuk Baineo di Desa Kuanheum. Batas-batas wilayah Lilifuk yang ditutup sebagai daerah konservasi yaitu sejajar dengan garis pantai dengan luas: a) Lilifuk Gatal: 200 x 100 m, b) Lilifuk Gatal: 370 x 30 m, dan c) Lilifuk Baineo: 100 x 50 m. Batas-batas wilayah tersebut juga diberi tanda. Awalnya tanda yang diberikan berupa batu. Namun karena batu-batu tersebut sering dibongkar pada saat dibuka, maka batas tersebut diganti dengan menggunakan kayu.

Sejarahawalnya kepemilikan Lilifuk oleh suatu suku tertentu dikarena ditemukan wilayah tersebut oleh salah satu anggota suku tersebut sehingga dapat diklaim sebagai miliknya secara adat. Kesepakatan untuk menutup daerah tersebut dilakukan atas keinginan bersama dan diprakarsai oleh tokoh adat, pemerintah desa, tokoh agama serta masyarakat.

Terdapat 5 komponen masyarakat yang yang mengelola kearifan Lilifuk yaitu: tokoh agama, tokoh adat, pemerintah desa, masyarakat dan masyarakat luar desa. Menjadi penjaga sumberdaya khususnya perikanan adalah peran serta tokoh adat dan mereka pula yang membantu pemerintah desa dalam menghimpun informasi tentang gangguan dan pencurian ikan di dalam wilayah tersebut.

Tokoh agama dan pemerintah desa memiliki peran adalah sebagai pengambil kebijakan, pertimbangan serta pemberian dukungan di dalam penerapan aturan yang sudah dibuat oleh kelima komponen masyarakat. Pemerintah desa juga mempunyai peranan sumber penyebaran informasi kepada masyarakat luas kapan saat waktunya Lilifuk dibuka.

Masyarakat desa mempunyai peranan penting yaitu menjaga daerah Lilifuk dari pelanggaran-pelanggaran dan menaati segala bentuk peraturan yang sudah dibuat bersama.

Proses ritual adat biasanya dilakukan selama dua hari. Selama dua hari dilakukan penangkapan ikan pada saat dibukanya Lilifuk dilakukan oleh masyarakat desa maupun dari luar desa tersebut. Pembukaan Lilifuk biasanya dimulai dengan pesta adat dan ritual agama sebelum dilakukannya panen ikan di wilayah tersebut.

Dari hasil pengamatan yang dilakukan dapat diketahui bahwa Lilifuk 
merupakan salah satu pengelolaan sumber daya perikanan Community Based Management (CBM). Menurut Nikijuluw (2002),CBM merupakan suatu proses pemberianwewenang, tanggung jawab dan kesempatankepada masyarakat untuk mengelola sumberdaya kelautan dan perikanan sendiri denganmemperhatikan kebutuhan, keinginan, tujuan dan aspirasinya.

\section{Konsep Kearifan Lokal}

Ada dua unsur yang dimiliki hukum adat yaitu: (1) unsur kenyataan, bahwa adat itu dalam keadaan yang sama selalu diindahkan oleh rakyat; dan (2) unsur psikologis, bahwa terdapat adanya keyakinan pada rakyat, artinya adat mempunyai kekuatan hukum menurut Wignjodipoero (1967) dalam Sulaiman (2010).

Ketika sebuah hukum adat sudah bisa dikategorikan dalam kearifan lokal, maka bisa dijadikan pedoman dan salah satu alat dalam usaha pemberdayaan masyarakat yang bertujuan terhadap kondisi yang berkelanjutan yaitu berpihak kepada lingkungan, sosial tanpa meninggalkan aspek ekonominya.

Kearifan lokal bersifat kumulatif dengan kepercayaan yang turun temurun terkait antara hubungan masyarakat dengan lingkungan. Menurut beberapa ahli, kearifan lokal dibedakan dengan budaya dalam suatu masyarakat tertentu. Umumnya kearifan lokal memiliki efek secara langsung terhadap kelestarian lingkungan yang didiami masyarakat yang memiliki kearifan tersebut. Secara turuntemurun dan secara tradisional kearifan lokal tersebut sudah ada unutk mencegah akses yang terlalu terbuka yang tentunya dengan konsekuensi merusak menurut Belkes (1995) dalam Sulaiman (2010).

$$
\text { Menurut Sulaiman (2010) }
$$

mendefinisikan pengetahuan lokal secara lebih detil sebagai "pengetahuan yang yang dibangun oleh kelompok komunitas secara turun temurun terkait hubungannya dengan alam dan sumberdaya alam". Pengetahuan lokal masyarakat meliputi segenap pengetahuan tentang hal-hal yang terkait dengan lingkungan hingga pengetahuan sosial, politik dan geografis.

\section{Kearifan Lokal Dalam Konteks Pembangunan Sumberdaya Perikanan Berkelanjutan}

Konsep pembangunan

sumberdaya perikanan berkelanjutan adalah bagaimana mensinergiskan semua sumberdaya yang mendukung pengembangan perikanan berkelanjutan tersebut.

Konsep perikanan nasional adalah sebagai indikator kesehatan ekosistem, penguat kedaulatan bangsa, lokomotif ekonomi nasional, penghasil devisa bagi negara, sumber protein bangsa dan pengawal budaya bangsa. Sebagai pengawal budaya bangsa inilah kearifan lokal berperan sangat besar.

\section{Perkembangan Kearifan Lokal Lilifuk}

Lilifuk diwariskan oleh leluhur sejak tahun 1950 hingga sekarang dan dijaga oleh beberapa suku, dan kemudian pada saat panen maka akan dipanen oleh seluruh masyarakat sekitar melalui penyebaran undangan.

Awalnya Lilifuk hanyalah sebuah kolam alami tetapi kolam tersebut memberi hasil yang memuaskan kepada masyarakat setempat namun beberapa orang yang berasal dari suku yang berbeda saling membantu untuk menjaga kolam alami tersebut dengan diberi pembatas atau dipagari dengan batu karang dan pada waktu panen Lilifuk dibuka olehpara pemiliknya dengan mengundangmasyarakat sekitar untuk secara bersama-samamemanen hasil (ikan) yang ada dikolam.

Aturan dan sanksi diterapkan dalam pengelolaan sumber daya Lilifuk ini. Aturan yang terdapat dalam pengelolaan ini diantaranya tidak boleh mengambil hasil laut apapun yang terdapat di dalam wilayah Lilifuk, penggunaan alat tangkap yang dibolehkan pada saat buka Lilifuk adalah alat tangkap yang ramah lingkungan (serok dan tombak), serta mekanisme keikutsertaan dalam waktu buka Lilifuk yaitu membayar biaya masuk sebesar Rp. 5.000 per orang. Sanksi yang 
diterapkan bila terjadi pelanggaran diantaranya berupa uang sebesar Rp. 100.000 bagi masyarakat desa dan Rp. 350.000 bagi masyarakat di luar desa. Selain itu dikenakan denda babi/kambing, beras dan sarung.

\section{Model Pengelolaan dan Pemberdayaan} Konsep community based management dengan memberdayakan dan melibatkan masyarakat lokal sebagai salah satu stakeholder yang langsung bersentuhan dengan objek yang akan dikelola dan dimanfaatkan merupakan salah satu solusi dalam mengurangi ketidaksesuaian kebijakan pusat yang bersifat universal atau pukul rata ditengah karakteristik setiap wilayah sangat berbeda. Karakteristik yang berbeda ini bisa berupa budaya, kondisi alam, dan sumberdaya manusia setempat. Sehingga kita dapat memanfaatkan masyarakat lokal atau lembaga lokal jika ada akan membantu dalam kesesuaian kebijakan dan model yang akan diterapkan.

Dalam konteks kearifan lokal yaitu pengetahuan lokal yang memiliki keberpihakan dengan kelestarian lingkungan, jika dilihat pada kondisi yang sudah dijelaskan diatas, dapat kita cermati bahwa ada budaya setempat yang berpontensi sebagai kearifan lokal, yaitu dengan membatasi wilayah perairan yang dijaga oleh masyarakat dengan aturan dan sanksi berupa denda untuk setiap pelanggaran. Lilifuk hanya dlakukan dua kali dalam setahun dan ini dilakukan untuk pengembangan perikanan berkelanjutan.

\section{Membangun Model Pengelolaan Sumberdaya Berbasis Masyarakat}

Strategi membangun masyarakat pesisir yang ada di Desa Kuanheum dalam rencanapembangunan berkelanjutan berbasis masyarakat dapat dilakukan melalui dua pendekatan yaitu, yang sifatnya non struktural dan struktural. Kedua pendekatan ini diperlukan adanya kesepakatan lokal yang ada dilingkungan masyarakat yang dilindungi oleh pemerintah sebagai pelindung dari adanya kesepakatan lokal.

\section{Pendekatan Subyektif}

Pendekatan non struktural atau subyektik adalah pendekatan yang menempatkan manusia sebagai subyek yang mempunyai keleluasaan untuk berinisiatif dan berbuat menurut kehendaknya dengan diiringi pemahaman konsep atau wawasan sebagai landasan guna mencapai sasaran yang akan dicapai.

Pada saat pembukaan Lilifuk masyarakat merasakan manfaat ekonomi yang dirasakan oleh masyarakat adalah manfaat untuk individu maupun rumah tangganyakarena dapat menambah penghasilan daripenangkapan ikan pada saat buka Lilifuk.

Manfaat sosial dirasakan oleh masyarakat untuk kehidupan kelompok atau lingkungan sosialnya seperti meningkatkan hubungan sosial antara satu rumah tangga dengan rumah tangga lainnya serta menjaga hubungan sosial dengan tetangga sekitarnya yang ikut pada waktu buka Lilifuk, bahkan dengan masyarakat di luar desa tersebut.

Manfaat sosial lainnya adalah waktu buka Lilifuk memberikan hiburan gratis bagi masyarakat dengan berekreasi menonton acara buka Lilifuk tersebut. Selain itu, Lilifuk menjaga tradisi setempat karena Lilifuk merupakan warisan orang tua.

\section{Pendekatan struktural.}

Tujuan pokok pendekatan struktural adalah terbentuknya struktur, lembaga lokal dan sistem yang terbentuk tersebut, antara semua aspek dan sistem kehidupan, baik di wilayah pesisir dan laut maupun aspek pendukung yang terkait, termasuk aspek sosial, ekonomi dan lingkungan. Dengan penataan aspek struktural, diharapkan masyarakat mendapatkan kesempatan lebih luas untuk dapat memanfaatkan sumber daya alam secara berkelanjutan. Selain itu membangun struktur sosial dan ekonomi tersebut diharapkan dapat menciptakan adanya peran vital bagi masyarakat untuk ikut serta melindungi sumber daya alam dari ancaman. yang datang baik dari dalam maupun dari luar. Sehingga dapat dilakukan dengan langkah - langkah 

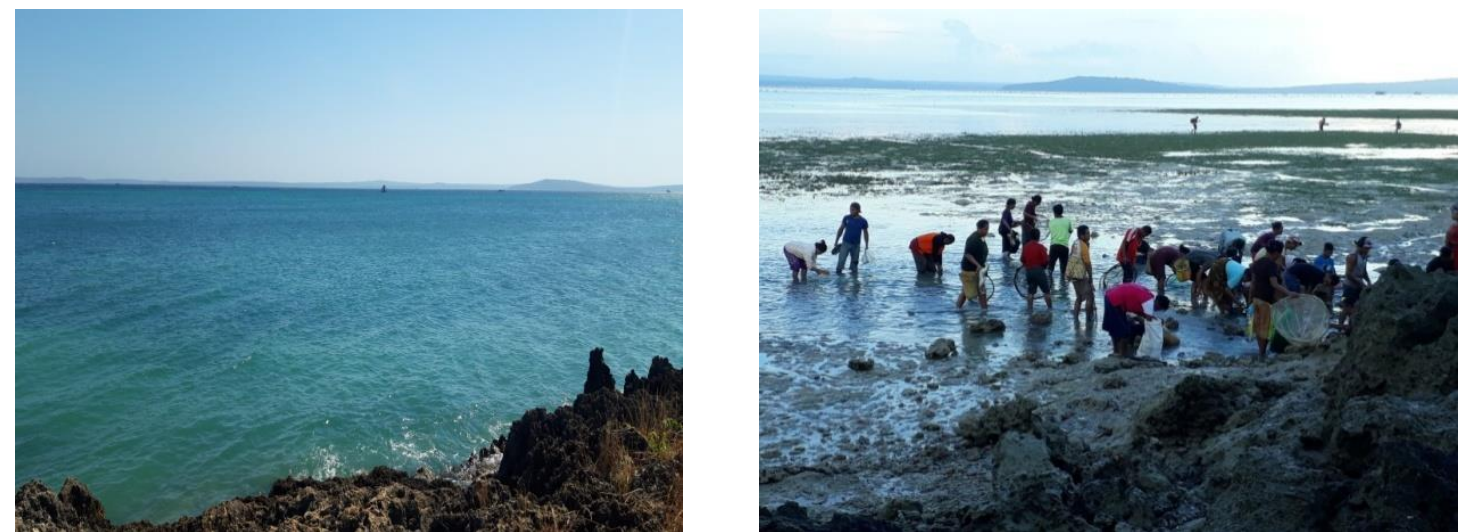

Gambar 1. Proses Penangkapan Ikan di Lilifuk

strategi sebagai berikut : a. Membentuk lembaga lokal. b.Pengembangan akses masyarakat terhadap proses pengambilan keputusan. c.Peningkatan akses masyarakat terhadap informasi.

Masyarakat di sekitar Lilifuk berusaha menjaga lingkungan pesisir karena sebagian besar wilayah perairan tersebut digunakan masyarakat untuk usaha penangkapan ikan yang merupakan mata pencaharian utama masyarakat. Apabila lingkungan tidak dijaga maka akan berdampak pada produksi penangkapan ikan. Namun begitu, beberapa hal yang tidak dapat dihindari oleh masyarakat yang dapat mengancam sumber daya perairan di sekitar Lilifuk dan pengelolaannya baik pengaruh dari luar maupun dari dalam.

Berdasarkan pengamatan yang dilakukan masyarakat di sekitar Lilifuk berusaha untuk menjaga lingkungan pesisir karena sebagian besar wilayah perairan tersebut digunakan masyarakat untuk usaha penangkapan ikan yang merupakan mata pencaharian utama masyarakat selain bertani.

Berdasarkan hal tersebut, masyarakat menyadari pentingnya keberadaan Lilifuk dengan segala manfaatnya yang langsung dirasakan oleh mereka. Keberlanjutan Lilifuk akan selalu dijaga oleh masyarakat, karena dengan merusaknya berarti masyarakat akan mendapatkan dampaknya juga. Oleh karena itu masyarakat berusaha untuk menjaga kawasan perairan di sekitar Lilifuk baik dari dalam lingkungan maupun dari luar lingkungannya.

\section{KESIMPULAN}

Kearifan lokal yang ada di Desa Kuanheum bersifat turun-temurun yang dalam pelaksanaannya selalu melalui proses musyawarah. Dalam musyawarah terdapat komponen masyarakat yang terlibat yaitu: tokoh-tokoh adat, pemerintah desa dan masyarkat. Konsep pengelolaannya bersifat community based management dengan memberdayakan dan melibatkan masyarakat lokal sebagai salah satu stakeholder yang langsung bersentuhan dengan objek yang akan dikelola dan dimanfaatkan. Model membangun pengelolaan berbasis pada pendekatan subyektif dan pendekatan struktural

\section{UCAPAN TERIMA KASIH}

Ucapan terima kasih terutama ditujukan kepada Pusat Pengembangan Penelitian dan Pengabdian Masyarakat Politekni Pertanian Negeri Kupang yang telah mendanai penelitian ini. Ucapan terima kasih dapat juga disampaikan kepada pihak-pihak yang membantu pelaksanaan penelitian. 


\section{DAFTAR PUSTAKA}

Boikh, L.I. 2010. Persepsi Masyarakat Terhadap Daerah Perlindungan Laut Berbasis Masyarakat dengan Kearifan Lokal di Desa Bolok. Skripsi. Fakultas Perikanan dan Ilmu Kelautan Universitas Kristen Artha Wacana. Kupang, Nusa Tenggara Timur. 83 hal.

Fauzi, A. 2004. Ekonomi Sumber Daya Alam dan Lingkungan. Teori dan Aplikasi. Jakarta: PT. Gramedia Pustaka Utama. 259 hal. 002).

Idrus, Muhammad. 2009. Metode Penelitian Ilmu Sosial, Pendekatan Kualitatif dan Kuantitatif, Jakarta : Erlangga

Juniarta Hagi Primadasa, et.all. Kajian Profil Kearifan Lokal Masyarakat Pesisir Pulau Gili Kecamatan Sumberasih Kabupaten Probolinggo Jawa Timur. Jurnal ECSOFiM Vol. 1 No. 1, 2003

Mardoyo. 2008. Pengendalian Mutu Kinerja dan Kompetensi. Jurnal Penelitian

Nikijuluw, V.P.H. 2002. Rezim Pengelolaan Sumber Daya Perikanan. Jakarta: Pustaka Cidesindo. 254 hal.

Ridwan, Nurma A. 2007. Landasan Keilmuan Kearifan Lokal. Jurnal Studi Islam dan Budaya. Purwokerto

Sulaiman. 2010. Model Alternatif Pengelolaan Perikanan Berbasis Hukum Adat Lhaot Di Kabupaten Aceh Jaya Menuju Keberlanjutan Lingkungnaan Yang Berorientasi Kesejahteraan Masyarakat.Universitas Diponegoro. Semarang.

Surbakti,J A. Rikka Welhelmina Sir, Tingkat Keramahan Lingkungan Alat Tangkap Bagan Di Perairan
Oesapa Teluk Kupang, Nusa Tenggara Timur. Saintek Perikanan Vol.15 No.1 : 41-45, Agustus 2019 DOI: $\underline{10.14710 / \mathrm{ijfst} \text {.15.1.41-45 }}$ 
